\title{
Phytochemical, pharmacological and biological properties of Ajuga turkestanica (Rgl.) Brig (Lamiaceae)
}

\author{
Bakhodir Mamarasulov, Kakhramon Davranov and Dilfuza Jabborova* \\ Institute of Microbiology of the Academy of Sciences of Uzbekistan, Tashkent, Uzbekistan \\ *Laboratory of Medicinal Plants Genetics and Biotechnology, Institute of Genetics and Plant Experimental Biology, Academy of Sciences of \\ Uzbekistan, Tashkent, Uzbekistan
}

\begin{tabular}{l} 
Article Info \\
\hline Article history \\
Received 14 April 2020 \\
Revised 3 June 2020 \\
Accepted 5 June 2020 \\
Published online 30 June 2020 \\
Keywords \\
Ajuga turkestanica (Rgl.) Brig \\
Pharmacological activity \\
Phytoecdysteroids \\
Turkesterone \\
Ecdysterone \\
Turkesterone \\
Cyasterone
\end{tabular}

\begin{abstract}
Ajuga turkestanica (Rgl.) Brig (Lamiaceae) is a medicinal, herbaceous flowering species which has been traditionally used in Uzbekistan for cure of various human diseases like, heart disease, muscle aches and stomach problems. This plant possesses diverse pharmacological activities, antibacterial activity, hypoglycemic activity, hypolipidemic action, anabolic activity: growth promotion, increase in protein synthesis in skeletal muscle cells, hepatoprotection activities. Several compounds have been isolated from $A$. turkestanica, which display a wide spectrum of biological and pharmacological activities. This review provides scientific information on the biologically active substances of the medicinal plant A. turkestanica, their structure, pharmacology, and applications in pharmaceuticals and medicine.
\end{abstract}

\section{Introduction}

There are more than 4,500 vascular plants in the flora of Uzbekistan, 9\% of which are endemic, and the medicinal plant Ajuga turkestanica (Rgl.) Brig which is the object of our study, is also an endemic species. The medicinal plant, A. turkestanica is distributed as an endemic species in the Pamir Alay mountains of Boysun district. The mountainous areas of Boysun include the Hissar and Pamir Alay mountains. The Pamir-Alay is a mountain system in Tajikistan, Kyrgyzstan and Uzbekistan, encompassing various mountain ranges extending west from the Tian Shan Mountains, and located north of the main range of Pamir. It stretches between the valleys of the rivers Syr Darya (Fergana Valley) to its north and Vakhsh to its south. Part of these mountainous areas falls on the Surkhandarya region of Uzbekistan. According to the scientific literature, the flora of Surkhandarya is second only to the Transcaucasian republics in terms of species composition. This shows that Surkhandarya is rich in plants. There are more than 4,500 plant species in the country, of which 1646 species are found in the region. This fact shows that

Corresponding author: Dr. Kakhramon Davranov Professor and Director, Institute of Microbiology of the Academy of Sciences of Uzbekistan, Tashkent, Uzbekistan

E-mail: k.davranov@mail.ru; bakhodir85@mail.ru

Tel.: +99-8941592882; +99-8901888830

Copyright () 2020 Ukaaz Publications. All rights reserved.

Email: ukaaz@yahoo.com; Website: www.ukaazpublications.com the flora of Surkhandarya region is rich and diverse. For this reason, there has long been a great interest in the study of the flora of this country. The flora of Surkhandarya region is part of the flora of Uzbekistan, of which 126 species are listed in the Red Book. These plant species belong to 105 families. A. turkestanica accumulates high levels of plant secondary compounds, known as phytoecdysteroids, which are the purported bioactive constituents and the focus of this research. The genus Ajuga is the part of the Lamiaceae family, comprisesed of 50 species, and about 300 taxa (including subspecies and varieties), distributed in Asia, Africa, Australia, North America, and Europe.

\section{The use of Ajuga plants in traditional medicine}

A. turkestanica is a widely used medicinal plant in the pharmaceutical industry, antimalarial and many species of medicinal plants, belonging to the Ajuga family (Njoroge and Bussmann, 2006), hypoglycemic (El-Hilaly et al., 2004), several scientific studies have shown its anti-inflammatory biological activity.

Studies of the phytochemical properties of Ajuga medicinal plants have shown that plants contain biologically active secondary metabolites, such as iridoids, diterpenes, phytoecsteroids, flavonoids, sterol glycosides and phenylethonoid glycosides. The pharmacology and therapeutic value of plants including Ajuga reptans have been described as early as 1948 (Newman, 1948). In 
East Africa, plants of the genus Ajuga have been used as a remedy for fever, toothache, dysentery, and high blood pressure (Baytop, 1984; Githinji and Kokwaro, 1993). Medicinal plants belonging to the Ajuga family for the treatment of diabetes in North Africa (Ziyyat et al., 1997; Jouad et al., 2001; Bnouham et al., 2002; Tahraoui et al., 2006; Eddouks et al., 2007), as well as various diseases associated with gastrointestinal diseases (Baytop, 1984; Bellakhdar et al., 1991) and finally high degree of effect. From the scientific literature, it is known that it is widely used in pharmaceuticals as an anthelmintic drug (Wessner et al., 1992; Rodriguez-Hahn et al., 1994; Yun et al., 1998).
The results of scientific research among medicinal plant species belonging to the Ajuga family show that plants belonging to this family, are antibacterial (Chen et al., 1996a; Chen et al., 1997; Bennaghmouch et al., 2001), antifungal (Kariba, 2001), in inflammatory diseases (Marc et al., 2008), as an antioxidant (Chenni et al., 2007), as an agent against insects and their larvae (Camps et al., 1981a; Camps and Coll, 1993; Bremner et al., 1998; Bondì et al., 2000; Fekete et al., 2004) are used in pharmaceuticals and agriculture.

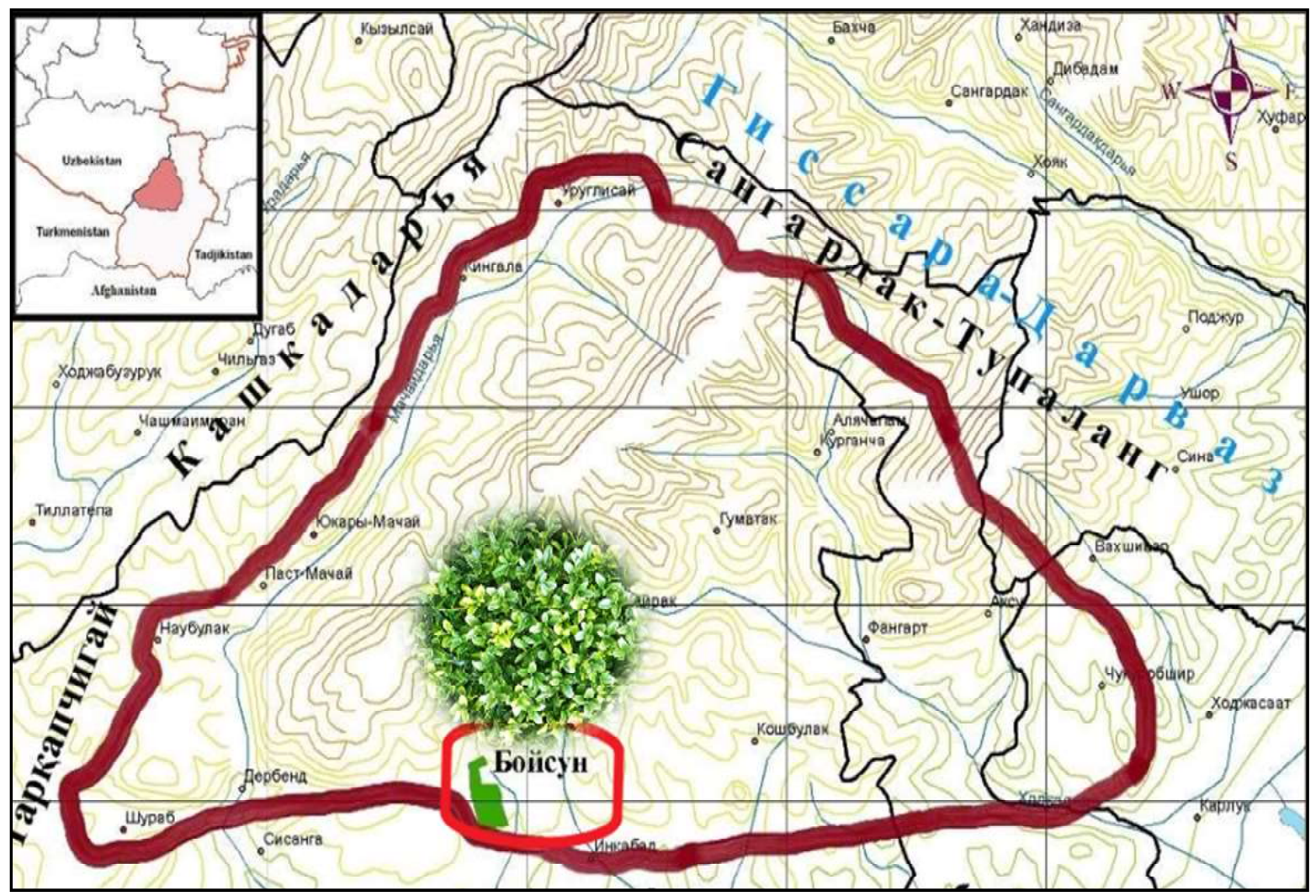

Figure 1: The area where the medicinal plant A. turkestanica is spread is Boysun district of Surkhandarya region (Botanical and Geographical map of Boysun).

\section{Compounds isolated from plants of genus Ajuga}

Like many medicinal plants belonging to the Lamiaceae family, biologically active secondary metabolites used in traditional medicine, pharmaceuticals, have been isolated from plants belonging to the genus Ajuga. For example, terpenoids (Camps et al., 1979; Camps et al., 1981b; Camps et al., 1982a; Camps et al., 1982b; Camps et al., 1984a; Camps et al., 1984b; Beauchamp et al., 1996; Chen et al., 1996a; Chen etal., 1997; Bremner et al., 1998; Cantrell et al., 1999; Ben Jannet et al., 1999; Ben Jannet et al., 2006; Castro et al., 2008), sterols (Cantrell et al., 1999; Akbay et al., 2003a), iridoids and glycosides (Kotenko et al., 1993; Takasaki et al., 1998;
Akbay et al., 2003b), quinones (Khan et al., 1999a). Biologically active secondary metabolites have been isolated. There are many different types of medicinal plants on Earth. Among them are plant species of special interest. Such plants are plants of the genus Ajuga, which produce from their bodies biologically active secondary metabolites of phytoecteroid nature (Aliotta and Pollio, 1994; Baltaev, 2000; Báthori and Pongrâcz, 2005). Biologically active secondary metabolites, such as exteroids, diterpenes, phytoexteroids, flavonoids, glycosides, were isolated from the Uzbek. endemic plant $A$. turkestanica. 
Table 1: Some biologically active substances isolated from plants of the genus Ajuga

\begin{tabular}{|c|c|c|c|}
\hline Medicinal plant & Family & Compounds & Reference \\
\hline Ajuga australis $\mathrm{R} . \mathrm{Br}$ & Lamiaceae & $\begin{array}{l}\text { Amarasterone A } \\
\text { Cyasterone } \\
\text { Ecdysone } \\
\text { 20-Hydroxyecdysone } \\
\text { Makisterone A }\end{array}$ & Darvas et al. (1998) \\
\hline A. bracteosa Benth & Lamiaceae & $\begin{array}{l}\text { Cyasterone } \\
20 \text {-Hydroxyecdysone }\end{array}$ & Darvas et al. (1998) \\
\hline A. chamaepitys & Lamiaceae & $\begin{array}{l}\text { Cyasterone } \\
\text { 20-Hydroxyecdysone } \\
\text { Makisterone A }\end{array}$ & Camps et al. (1985) \\
\hline A. chameacistus & Lamiaceae & $\begin{array}{l}\text { Cyasterone } \\
20 \text {-Hydroxyecdysone }\end{array}$ & Kubo et al. (1982) \\
\hline A. chia Schreb & Lamiaceae & $\begin{array}{l}\text { Cyasterone } \\
20 \text {-Hydroxyecdysone }\end{array}$ & $\begin{array}{r}\text { Ikan and Ravid (1971) } \\
\text { Makhsudov and Saatov (1995) } \\
\text { Usmanov et al. (1971) }\end{array}$ \\
\hline A. ciliate & Lamiaceae & 20-Hydroxyecdysone & Matsuoka et al. (1969) \\
\hline A. decumbens Thunb & Lamiaceae & $\begin{array}{l}\text { Ajugalactone } \\
\text { Ajugasterone C } \\
\text { Cyasterone } \\
\text { Decumbesterone A } \\
\text { 20-Hydroxyecdysone }\end{array}$ & $\begin{array}{l}\text { Koreeda et al. (1971) } \\
\text { Imai et al. (1969a) } \\
\text { Takasaki et al. (1999) }\end{array}$ \\
\hline A. incisa Maxim & Lamiaceae & $\begin{array}{l}\text { Ajugasterone B } \\
\text { Cyasterone } \\
\text { 20-Hydroxyecdysone } \\
\text { Polypodine B }\end{array}$ & Imai et al. (1969a) \\
\hline A. iva Schreb & Lamiaceae & $\begin{array}{l}\text { Ajugasterone B } \\
\text { Cyasterone } \\
\text { 24(28)-Dehydromakisterone A } \\
\text { 24,25-Dehydroprecysterone } \\
\text { 23-Hydroxycyasterone } \\
\text { 24-Hydroxycyasterone } \\
\text { 20-Hydroxyecdysone } \\
\text { Makisterone A } \\
\text { 22-Oxocyasterone (22-dehydrocyasterone)] }\end{array}$ & $\begin{array}{r}\text { Coll et al. (2007) } \\
\text { Knafagy et al. (1979) } \\
\text { Wessner et al. (1992) } \\
\text { Sabri et al. (1981) } \\
\text { Ikan and Ravid (1971) }\end{array}$ \\
\hline A. japonica Miq & Lamiaceae & $\begin{array}{l}\text { Ajugasterone C } \\
\text { Cyasterone } \\
\text { 20-Hydroxyecdysone }\end{array}$ & Imai et al. (1969b) \\
\hline A. laxmanni Benth & Lamiaceae & $\begin{array}{l}\text { 20-Hydroxyecdysone } \\
\text { Makisterone A }\end{array}$ & $\begin{array}{r}\text { Darvas et al. (1998) } \\
\text { Bergamasco and Horn (1983) }\end{array}$ \\
\hline A. linearifolia Pampan & Lamiaceae & $\begin{array}{l}\text { Cyasterone } \\
20 \text {-Hydroxyecdysone }\end{array}$ & $\begin{array}{r}\text { Darvas et al. (1998) } \\
\text { Bergamasco and Horn (1983) }\end{array}$ \\
\hline Ajuga macrosperma var. breviflora & Lamiaceae & $\begin{array}{l}\text { Ajugacetalsterone C } \\
\text { Ajugacetalsterone D } \\
\text { Breviflorasterone } \\
\text { Cyasterone } \\
\text { 20-Hydroxyecdysone } \\
\text { 20-Hydroxyecdysone-2-acetate } \\
\text { 20-Hydroxyecdysone-3-acetate } \\
\text { Makisterone A }\end{array}$ & Castro et al. (2008) \\
\hline A. multiflora & Lamiaceae & $\begin{array}{l}\text { Cyasterone } \\
\text { 20-Hydroxyecdysone } \\
\text { Makisterone A }\end{array}$ & $\begin{array}{r}\text { Darvas et al. }(1998) \\
\text { Yul et al. }(1998) \\
\text { Coll et al. }(2007)\end{array}$ \\
\hline
\end{tabular}




\begin{tabular}{|c|c|c|c|}
\hline Medicinal plant & Family & Compounds & Reference \\
\hline A. nipponensis Makino & Lamiaceae & $\begin{array}{l}\text { Ajugacetalsterone A } \\
\text { Ajugacetalsterone B } \\
\text { Ajugasterone C } \\
\text { Ajugasterone D } \\
\text { Cyasterone } \\
\text { Cyasterone-22-acetate } \\
\text { 22-Dehydrocyasterone-2-glucoside } \\
\text { 20-Hydroxyecdysone } \\
\text { 22-Oxocyasterone (22-dehydrocyasterone) } \\
\text { Polypodine B }\end{array}$ & $\begin{array}{r}\text { Coll et al. (2000) } \\
\text { Zeng et al. }(2003) \\
\text { Chou and Lu (1980) } \\
\text { Lafont (1989) } \\
\text { Imai et al. (1969a) }\end{array}$ \\
\hline A. reptans $\mathrm{L}$. & Lamiaceae & $\begin{array}{l}\text { Ajugalactone } \\
\text { Ajugasterone B } \\
\text { Cyasterone } \\
\text { 20-Hydroxyecdysone } \\
\text { 20-Hydroxyecdysone-22-acetate } \\
\text { 29-Norcyasterone } \\
\text { 29-Norcyasterone-2-acetate } \\
\text { 29-Norsengosterone } \\
\text { Polypodine B } \\
\text { Reptansterone } \\
\text { Sengosterone } \\
\text { Viticosterone E }\end{array}$ & $\begin{array}{r}\text { Camps et al. (1982a) } \\
\text { Calcagno et al. (1996) } \\
\text { Alexeeva et al. (1998) } \\
\text { Hikino et al. }(1968)\end{array}$ \\
\hline A. taiwanensis & Lamiaceae & $\begin{array}{l}\text { Ajugalide E } \\
\text { Cyasterone } \\
\text { Cyasterone-22-acetate }\end{array}$ & Chan et al. (2005) \\
\hline A. reptans var. atropurpurea & Lamiaceae & $\begin{array}{l}\text { Ajugalactone } \\
\text { Cyasterone } \\
\text { Cyasterone-3-acetate } \\
\text { 2-Dehydroajugalactone } \\
\text { 3-Dehydroajugalactone } \\
\text { 22-Dehydro-12-hydroxycyasterone } \\
\text { 22-Dehydro-12-hydroxy-29-norcyasterone } \\
\text { 22-Dehydro-12-hydroxy-29-norsengosterone } \\
\text { 22-Dehydro-12-hydroxysengosterone } \\
\text { 5,29-Dihydroxycapitasterone }\end{array}$ & $\begin{array}{l}\text { Calcagno et al. (1996) } \\
\text { Alexeeva et al. (1998) }\end{array}$ \\
\hline
\end{tabular}

\section{Morphobiological characteristics of the medicinal plant A. turkestanica}

A. turkestanica in the family Lamiaceae, was found in the Boysun mountainous region of Central Asia, Uzbekistan. This is a perennial herb that blooms in spring and forms pale purple inflorescences. The locals $A$. turkestanica, which means "sanabor", i.e., charmer, traditionally use it as a tonic and liver protection agent (Syrov et al., 2003). The genus Ajuga is traditionally used for medicinal properties in many regions of the world (Hilaly et al., 2004).

\section{Description}

The body length of the plant reaches $40-60 \mathrm{~cm}$. The stems are ascending, sometimes lying, hairy, hollow, thematically unknown 4-sided. The leaves are simple, elliptical or oblong, with a pointed tip, with straight edges. The lower part of the stem is located opposite the leaf strip. The flowers are small, light pink, located in the axils of two leaves. The fruit consists of four nuts, which are characteristic of the whole family of Lamiaceae.

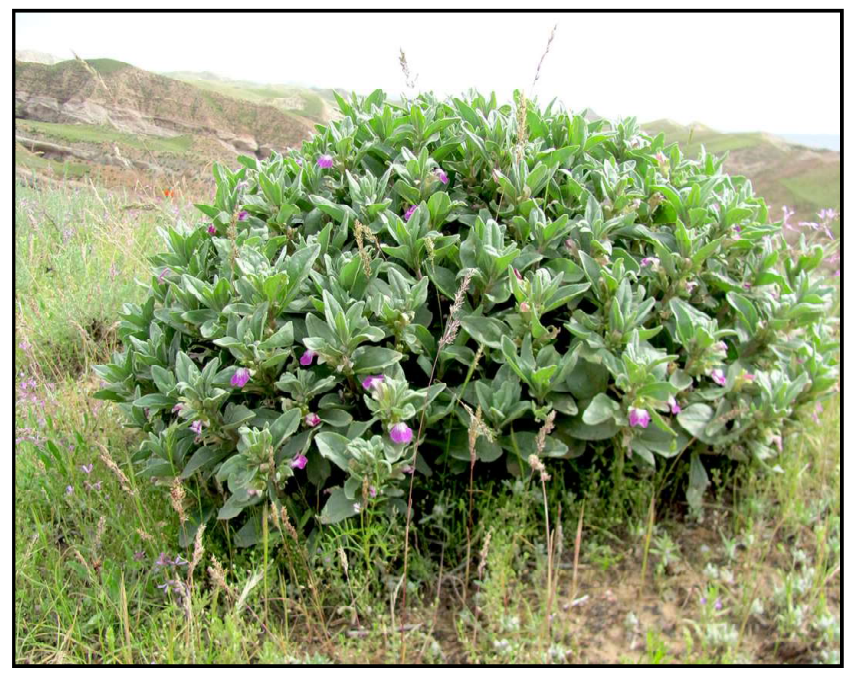

Figure 2: Ajuga turkestanica (Rgl.) Brig. 


\section{Distribution}

Pamir Alay, South-western Gissar (Kokhitang and Boysun), low mountains in southern Tajikistan. Grows on clay, petrous and rubbly slopes, rocks, taluses. Reaches elevation of up to $2500 \mathrm{~m}$.

Feature: Medicinal

Used part: Root and body parts
Ingredients: Phytoecdizon contains: turkesterone, ecdisterone, ciasterone, ayugstan, (on the leaf): ecdisterone, ayugalactone, ayugasterone and other substances.

Use in traditional medicine: In folk medicine, this plant is used to prevent obesity, hair loss and gastrointestinal diseases. In medicine, substances derived from this plant are used in the treatment of cardiovascular diseases (myocardial infarction) (Chandel and Bagai, 2010; Sher and Al-Yemeni, 2011; Kaithwas et al., 2012; Ahmad et al., 2012; Ahmad et al., 2014; Jan et al., 2014).

Table 2: Ethnobotany and traditional use of plants of $A$. turkestanica

\begin{tabular}{|l|l|l|l|l|l|}
\hline Name & Flowers & Phenology & Population status & $\begin{array}{l}\text { Pharmacological } \\
\text { properties and treatments }\end{array}$ & Traditional use \\
\hline $\begin{array}{l}\text { A. turkestanica } \\
\text { (Rgl.) Brig. }\end{array}$ & $\begin{array}{l}\text { Solitary, } \\
\text { axillary(bright } \\
\text { pink-purple) }\end{array}$ & $\begin{array}{l}\text { Flowers in } \\
\text { May-June, } \\
\text { fruits by the } \\
\text { end of May. }\end{array}$ & $\begin{array}{l}\text { Usually found in } \\
\text { populations of 10-300 } \\
\text { individuals, and in greater } \\
\text { numbers in herbaceous } \\
\text { Artemisiagrass complexes. }\end{array}$ & $\begin{array}{l}\text { Anabolic activity and } \\
\text { cholagogic action }\end{array}$ & $\begin{array}{l}\text { Heart disease, muscle aches, } \\
\text { stomach problems } \\
\text { (Mamatkhanov et al., 1998; } \\
\text { Abdukadirov et al., 2004) }\end{array}$ \\
\hline
\end{tabular}

Table 3: Compounds isolated from some plants of A. turkestanica

\begin{tabular}{|l|l|l|}
\hline Na me & Compounds & Reference \\
\hline A. turkestanica & 20-Hydroxyecdysone-2,3-Acetonide, & Usmanov et al. (1971); Usmanov et al. (1973); Usmanov et al. (1974) \\
(Rgl.) Brig. & 20-hydroxyecdysone (20E), & Usmanov et al. (1975); Usmanov et al. (1977); Usmanov et al. (1978) \\
& $\begin{array}{l}\text { ecdysterone, turkesterone, cyasterone, } \\
\text { Shimomura et al. (1989a); Shimomura et al. (1989b); Kotenko et al. (1993) } \\
\text { ajugasterone, ajugalactone, } \\
\text { cyasterone-22 acetate and } \\
\text { phytoecdysteroids }\end{array}$ & $\begin{array}{l}\text { Syrov et al. (1997); Tajasaki et al. (1998); Wu et al. (1998); Tsuji et al. (1999) } \\
\text { Wu et al. (2000); Abdukadirov et al. (2004); Abdukadirov et al., (2005); } \\
\text { Ramazanov and Syrov et al. (2006); Grace et al. (2008) }\end{array}$ \\
\hline
\end{tabular}

\section{Phytochemical profile of the medicinal plant A. turkestanica}

The biological activity of secondary biologically active meobolites isolated from the underground and upper parts of the A. turkestanica, medicinal plant is related to the presence of phytocidsteroid compounds in the plant. These biologically active substances do not have androgenic properties. Experiments in animals have shown that these compounds have a tonic effect and enhance resistance to various stress factors (Syrov et al., 1986; Mamatkhanov et al., 1998). In laboratory experiments in rats, it was found that these bioactive substances reduce the area of necrosis that occurs after myocardial infarction (Kurmukov, 1991). Drugs based on biologically active compounds of the medicinal plant $A$. turkestanica are approved for use in Uzbekistan in the treatment of myocardial infarction, post-infarction recovery and treatment of hypoxic malnutrition in the fetus (Kurmukov and Ermishina, 1992; Kurmukov et al., 1991). Ecsteroids cause a decrease in the amount of cholesterol and glucose in the blood, resulting in a positive effect on the liver and intestines due to increased protein synthesis and increase the permeability of the protective effect of nerve tissue. The bioactive substance turkesterone isolated from the plant $A$. turkestanica is also widely used in the field of pharmacology as a biologically active agent with various pharmacological effects on the human body. Turkesterone has tonic properties. It stimulates mental and physical work, protects against the negative effects of various stressors. Under the influence of turkesterone, protein biosynthesis in the body is improved, especially in muscle tissue, erythropoiesis and immunogenesis are accelerated. Its use normalizes creatine synthesis, causes positive changes in carbohydrate, lipid and electrolysis metabolism, thereby improving metabolism and increasing the body's functional capacity. Turkesterone corrects impaired metabolism in organs and tissues in various pathological conditions (myocardial dystrophy, toxic damage to the liver and kidneys, anemia, destructive changes in the gastric mucosa and outer subcutaneous layer, bone fractures and other injuries) and helps restore their functions. It is a powerful antioxidant and delays premature aging of the body.

Phytoecdysteroids are plant steroids belonging to the family A. turkestanica and other Ajuga, mainly containing 19-29 carbon molecules. Most of them possess a cholest-7-en-6-one carbon skeleton (C27), synthesized from phytosterols in the cytosol through the mevalonic acid pathway. They display a wide array of benefits in agriculture and in folk medicine and are readily available in large amounts. In fact, their concentrations in plants are generally 
higher than those found in arthropods. They can be found in the leaves, roots, fruit, flowers, bark, rhizomes, and seeds, with their contents varying among organs, developmental stages, seasons, and habitats. The phytoexsteroids of the A. turkestanica plant exhibit physiological activity in insects and they affect a wide range of insects at very low concentrations and are not harmful to human or animal cells.

\section{Pharmacological and biological properties of the medicinal plant $A$. turkestanica}

Various extracts or purified compounds from A. turkestanica exhibit diverse biological characteristics, which are hypoglycemic, antitumor, antibacterial, antivirus, cytotoxic, as well as increase in insulin sensitivity in experimental diabetes. Herein, we describe the biological activities as well as its active extracts or compounds.

Table 4: Medicinal/pharmacological/biochemical properties of plant extract and compounds isolated from A. turkestanica

\begin{tabular}{|c|c|c|c|}
\hline $\begin{array}{l}\text { Medicinal } \\
\text { plant }\end{array}$ & $\begin{array}{l}\text { Medicinal/pharmacological/ } \\
\text { biological property }\end{array}$ & $\begin{array}{l}\text { Plant extract/chemicals isolated } \\
\text { from the plant }\end{array}$ & Reference \\
\hline \multirow{14}{*}{$\begin{array}{l}\text { A. } \text { turkestanica } \\
\text { (Rgl.) Brig. }\end{array}$} & Antibacterial activity & Phytoecdysteroids (in vitro) & Ulukanli et al. (2005) \\
\hline & Hypoglycemic activity & Ecdysteroids & $\begin{array}{l}\text { Kutepova et al. (2001) } \\
\text { El-Hilaly and Lyoussi (2004) }\end{array}$ \\
\hline & Hypolipidemic action & Ecdysteroids & Syrov et al. (1983) \\
\hline & $\begin{array}{l}\text { Stimulation of aquaporins - human } \\
\text { skin hydration }\end{array}$ & $\begin{array}{l}\text { Aq.- and EtOH- extract; } \\
\text { phytoecdysteroids (in vitro) }\end{array}$ & $\begin{array}{l}\text { Dumas et al. (2002) } \\
\text { Dumas et al. (2007) }\end{array}$ \\
\hline & $\begin{array}{l}\text { Stimulation of erythropoesis } \\
\text { (experimental anemia) }\end{array}$ & Silenoside A, turkesterone & Syrov et al. (1997) \\
\hline & $\begin{array}{l}\text { Renoprotection (in experimental } \\
\text { uremia) }\end{array}$ & $\begin{array}{l}\text { Phytoecdysterone (ecdysterone and } \\
\text { turkesterone) }\end{array}$ & Syrov and Khushbaktova (2001) \\
\hline & Anabolic activity: Growth promotion & Turkesterone; 2-deoxy-alphaecdysone & Syrov (2001) \\
\hline & $\begin{array}{l}\text { Stimulation of protein synthesis in the } \\
\text { liver } \\
\text { Increase in protein synthesis in } \\
\text { skeletal muscle cells } \\
\text { Increase in protein synthesis in liver }\end{array}$ & $\begin{array}{l}\text { Phytoecdysteroids (cyasterone, } \\
\text { ecdysterone, turkesterone) } \\
\text { Phytosteroids (in vitro and in vivo in rats) } \\
\text { Turkesterone (mouse) }\end{array}$ & $\begin{array}{l}\text { Syrov et al. (1978) } \\
\text { Gorelick-Feldman et al. (2008) } \\
\text { Syrov et al. (1978) }\end{array}$ \\
\hline & $\begin{array}{l}\text { Hepatoprotection (against liver } \\
\text { toxins) }\end{array}$ & $\begin{array}{l}\text { Ecdysterone, turkesterone, } \\
\text { cyasterone, iridoid glycosides (rats) }\end{array}$ & $\begin{array}{l}\text { Syrov et al. (1986) } \\
\text { Syrov et al. (1992a) } \\
\text { Syrov et al. (1998) } \\
\text { Syrov and Khushbaktova (2001) }\end{array}$ \\
\hline & Increase in blood flow & Ecdysteroids & Tsuji et al. (1999) \\
\hline & $\begin{array}{l}\text { Normalization of cell energetics and } \\
\text { lipid metabolism in the liver in } \\
\text { experimental diabetes }\end{array}$ & $\begin{array}{l}\text { Phytoecdysteroides, ecdysterone and } \\
\text { turkesterone }\end{array}$ & $\begin{array}{l}\text { Tashmukhamedova et al., (1985) } \\
\text { Syrov et al., (1992b) }\end{array}$ \\
\hline & $\begin{array}{l}\text { Reversal of mitochondrial dysfunction } \\
\text { in experimental hepatitis and diabetes }\end{array}$ & $\begin{array}{l}\text { Phytoecdysteroids (ecdysterone, } \\
\text { turkesterone and cyasterone) }\end{array}$ & Tashmukhamedova et al. (1986) \\
\hline & $\begin{array}{l}\text { Increase in insulin sensitivity in } \\
\text { experimental diabetes }\end{array}$ & Ecdysterone, ecdysteroid & Kosovskii et al. (1989) \\
\hline & Biliary secretagogue & $\begin{array}{l}\text { Phytoecdysteroids (ecdysterone, } \\
\text { turkesterone and cyasterone) }\end{array}$ & Syrov et al. (1986) \\
\hline
\end{tabular}

\section{Accumulation and biosynthesis of phytoecdysteroids in plant $A$. turkestanica}

A. turkestanica, a medicinal perennial plant from the family Lamiaceae (mint) and indigenous to Uzbekistan, provides a rich source of phytoecdysteroids (Abdukadirov et al., 2004). The phytoecdysteroid content of $A$. turkestanica includes $20 \mathrm{E}$, turkesterone, cyasterone, cyasterone 22-acetate, ajugalactone, ajugasterone $\mathrm{B}$, -ecdysone and ecdysone 2,3-monoacetonide along with iridoids and neo-clerodane diterpenes (Usmanov et al., 1971, 1973, 1975, 1978; Baltaev, 2000; Ramazanov, 2005; Grace et al., 2008). Air-dried leaves from $A$. turkestanica have been reported to contain $0.02 \% 20 \mathrm{E}$ and roots have been reported to contain $0.045 \%$ $20 \mathrm{E}$ and $0.052 \%$ turkesterone. Plant tissue culture strategies for phytoecdysteroid production in A. turkestanica have been investigated, including the development of callus cultures initiated from ovaries by and cell suspension and hairy root cultures initiated 
from leaves by Cheng et al. (2008). With the onset of germination, phytoecdysteroid levels stored in seeds initially decrease per fresh weight basis. As the plant develops, phytoecdysteroids are transported from the seeds to the cotyledons and then from the cotyledons to the first true leaves, and from each leaf set to the newly developing leaves, dynamically cycling and accumulating in the most apical leaves as the plant matures (Grebenok and Adler, 1991).

Let us now consider the synthesis of phytoecteroids in plants. Phytoecdysteroids belong to the terpene class of secondary metabolites and are biosynthesized through the mevalonic acid pathway in which mevalonic acid, cholesterol and acetyl-CoA are direct precursors (Bàthori and Pongrácz, 2005). The chemical structure of an ecdysteroid is characterized by a cyclopentanoperhydro-phenanthrene skeleton with an alkyl side chain at $\mathrm{C} 17$, containing a 7-en-6-one chromophore and several hydroxyl groups. The variations in number and location of hydroxyl groups on the steroid backbone account for the diversity of ecdysteroids in nature. 20 -Hydroxyecdysone (20E, also commonly reported as ecdysterone, -ecdysterone and-ecdysone) is the most prevalent and abundant phytoecdysteroid produced by plants, and a major component in phytoecdysteroid containing herbal extracts (Baltaev, 2000; Báthori et al., 2008). The diagram below shows a schematic representation of the mechanism of 20-Hydroxyecdysone synthesis in a plant (Figure 3). Additionally, levels of phytoecdysteroid accumulation in certain plant tissues, such as young developing leaves and floral structures, are high enough to cause premature molting and death in non-adapted insects and nematodes after ingestion (Dinan, 1992; Adler and Grebenok, 1995).

\section{The role of secondary metabolites derived from the $A$. turkestanica in human health}

The use of plants that have the property of synthesizing extrinsic compounds was also known to humans in ancient times. At present, modern methods of using these biologically active compounds in pharmaceuticals and medicine have been developed. Asteraceae, Lamiaceae plant families, which are now known in the world flora, are used in the production of ecdisterone and drugs based on them. In the flora of Uzbekistan, the plant $A$. turkestanica, which belongs to the family Lamiaceae, is also considered as a raw material rich in exdesteroid compounds. However, recent large-scale use of the plant has led to the species being listed as an endemic species. Compounds of ecsteroid nature isolated from the plant are widely used in medicine.

The physiological effects of ecdysteroids on the human body and warm-blooded animals are very diverse. They regulate mineral, carbohydrate, lipid and protein metabolism (Catalan et al., 1985; Kosovski et al., 1989; Kholodova et al., 1997). Their ability to normalize blood sugar can be useful in the treatment of diabetes (Takahashi and Nishimoto, 1992). Ecdysteroids also normalize cholesterol levels relieve liver inflammation caused by toxic hepatitis
Table 5: Identified compounds in chloroform extracted volatiles of the roots of $A$. turkestanica (Mamadalieva et al., 2013)

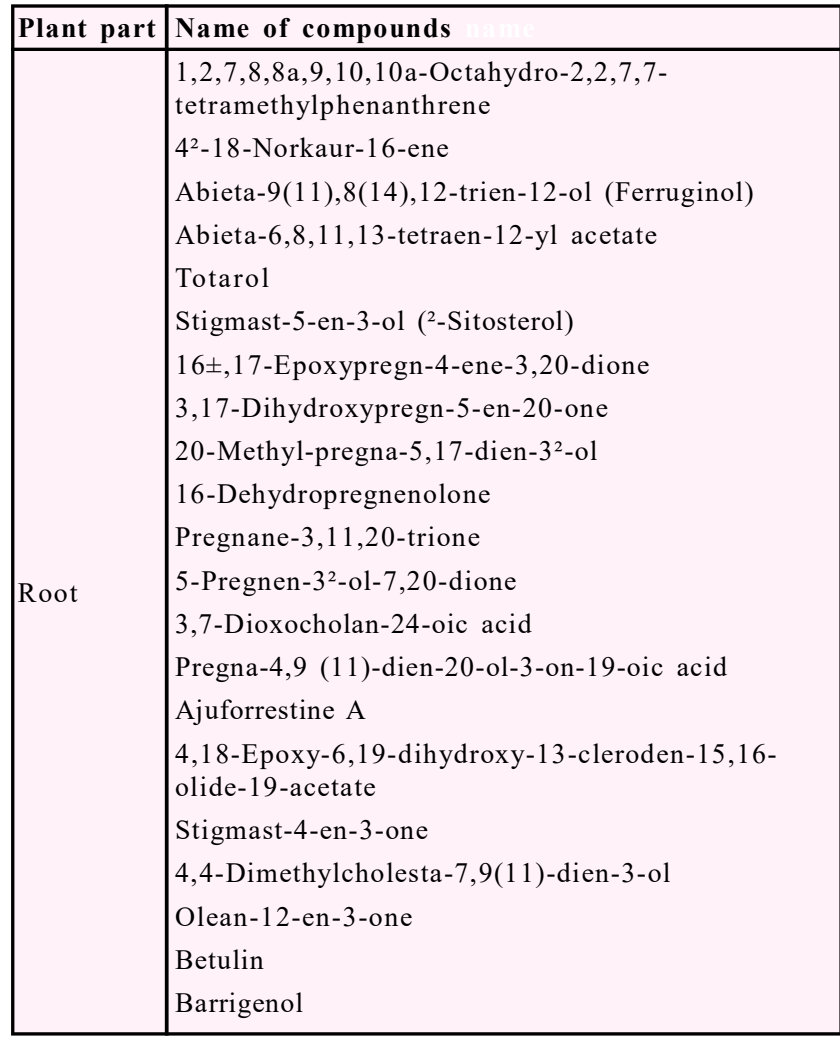

(Syrov et al., 1986); have the ability to duplicate the effect of vitamin $\mathrm{D}_{3}$, showing an antirachitic effect. They are known to exhibit antioxidant, antimicrobial (Volodin et al., 1999; Osipova et al., 2002), anti-inflammatory and wound healing properties. In addition, they have an immunomodulatory, adaptive, stress-protective and nootropic effects, as well as the anticonvulsant effect in spontaneous epilepsy (Hanaya et al., 1997). Stimulation of hematopoietic function (erythropoiesis), increased regeneration, and an increase in the concentration of red blood cells and hemoglobin in the blood have been established using 20-hydroxyecdysone (Syrov et al., 1997). There is an increase in the activity of elements of the blood protective system - lymphocytes and neutrophils (Trenin and Volodin, 1999), and an increase in the functions of phagocytosis. Acetates and 20-hydroxyecdysone derivatives also stimulated DNA biosynthesis in human and animal lymphocytes activated by polyclonal mitogens. The preventive and therapeutic effect of phytoecdysteroids in inducing anemia and leukopenia, in the treatment of threatening abortion, disorders in the activity of sexual function (Mirzaev et al., 2000), as well as menopausal syndrome caused by age-related changes in the regulation of the reproductive cycle. Ecdysteroids cause anabolic effects by stimulating protein biosynthesis in the liver, kidneys, and muscle muscles (Syrov et al., 1975). This property is widely used to correct body weight during the training process and to achieve high performance in professional sports. 


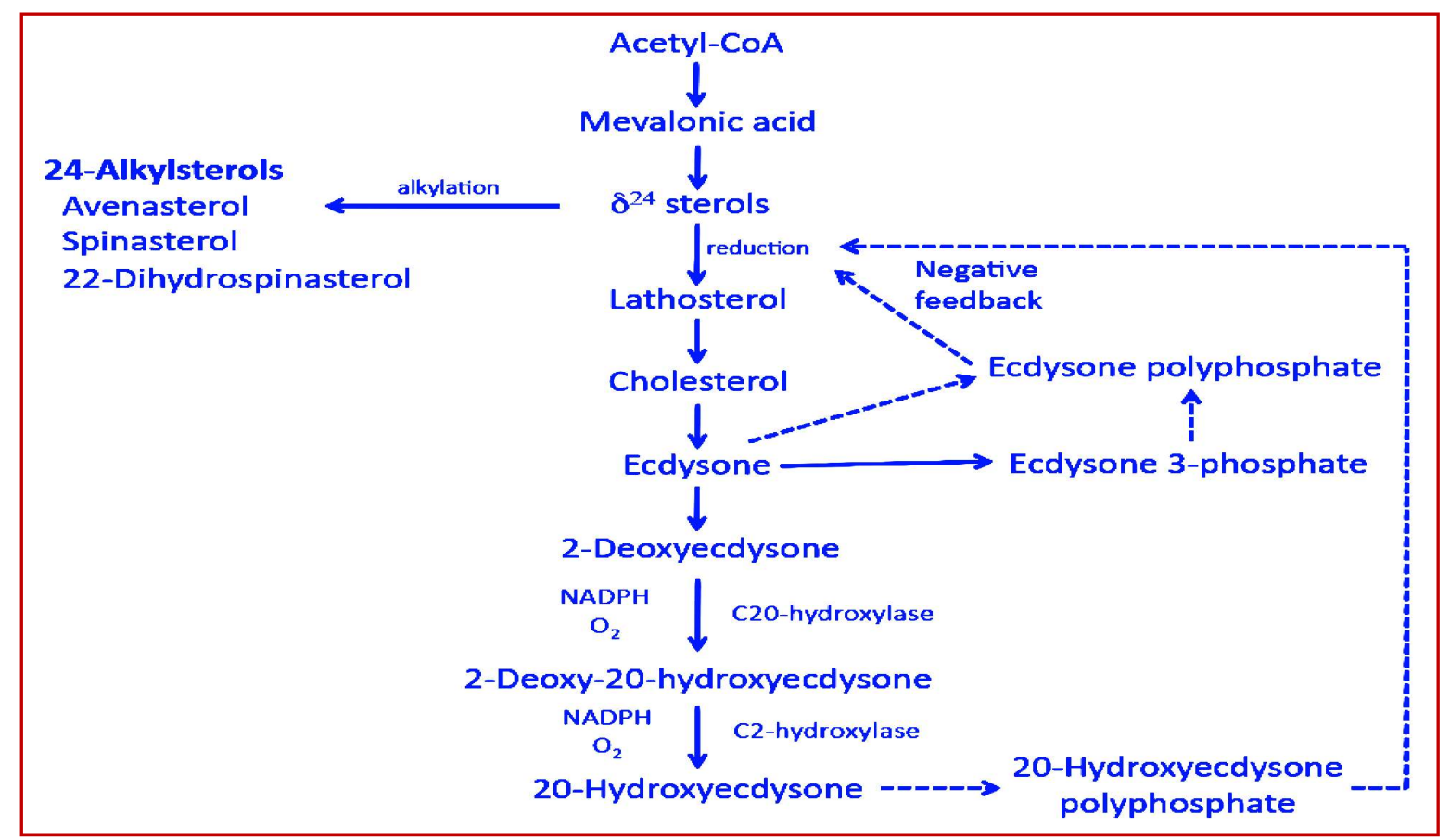

Figure 3: Mechanism of phytoecdysteroid biosynthetic formation compiled by Adler and Grebenok, (1999) and Bakrim et al. (2008).

The phytoecdysteroids and iridoids isolated from the A. turkestanica plant are listed below (Figure 4).

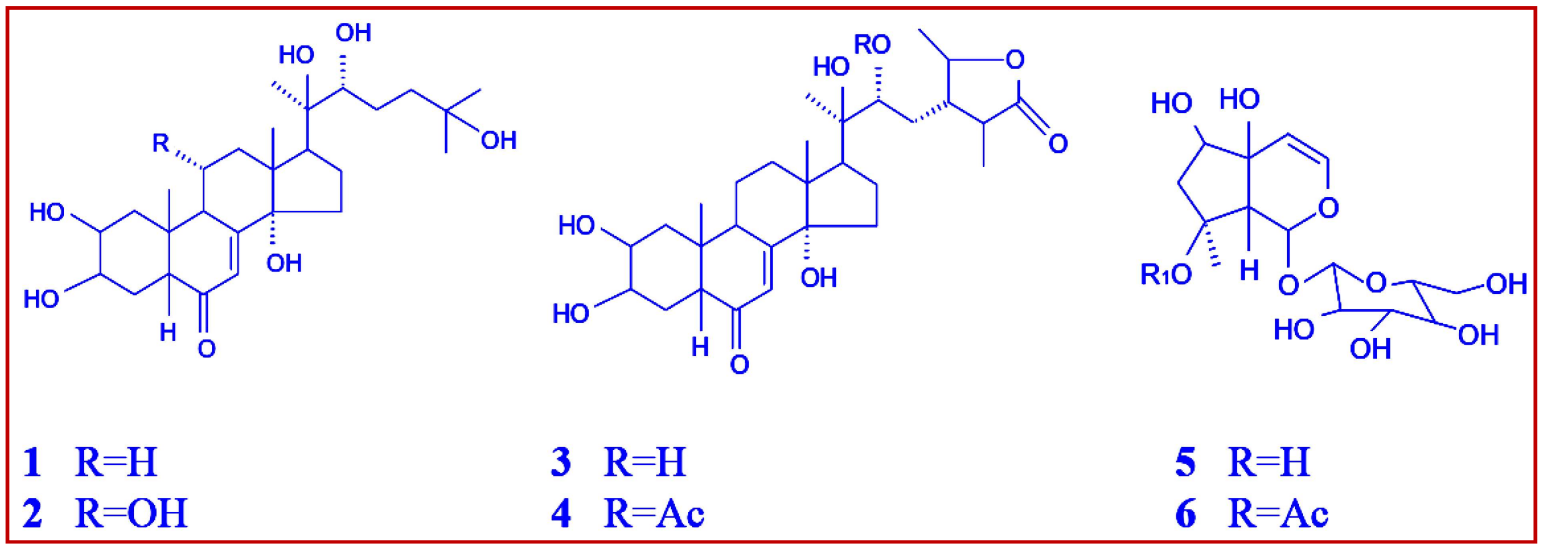

Figure 4: Chemical structure of phytoecdisteroids isolated from the medicinal plant, A. turkestanica (Mamadalieva et al., 2013).

In official scientific medicine, ecdysteroids containing natural compounds are used for disorders of the cardiovascular, central nervous and reproductive systems, as tonic and stimulating agents for mental and physical fatigue, decreased working capacity, impotence, and weakening of the functions of various organs can be used to heal wounds and ulcers, treat burns, improving sexual function, stimulating libido and eliminating discomfort in sexual life (Jakovljevic, et al., 2015; Atay et al., 2016; Yousaf et al., 2018). In sports and military medicine, preparations based on them serve to adapt and improve the health of a healthy person under conditions of limiting factors, including overcoming extreme physical and mental stress. Outside of official medicine, prophylactic use as adaptogenic, anabolic, antidepressant, hemorheological, nootropic and antitumor agents are most widespread (Ahmad et al., 2012; Ahmad and Habib, 2015; Chandel and Bagai, 2010). The pharmacodynamics of the adaptogenic effect of ecdysteroidcontaining plants are based on the effects of stimulation of specific and nonspecific immunity, increased resistance and increased boundaries of the body's adaptation to various infections, physical exertion, intoxication; improved tolerance of heat, cold, oxygen, lack of vet (Rani et al., 2017; Ali et al., 2019). The general tonic effect develops gradually and is expressed in increased stress resistance of the body, activation of metabolism, endocrine and autonomic regulation and is accompanied by increased appetite and secretion of the glands of the gastrointestinal tract, increased tone of the hollow organs (Jan et al., 2014; Kaithwas et al., 2012; Sher and Al-Yemeni, 2011). In addition to these effects, there is a restoration of reduced vascular tone, a slight increase in blood pressure and an improvement in the rhythm of the heart, not a pronounced psychostimulating effect. 


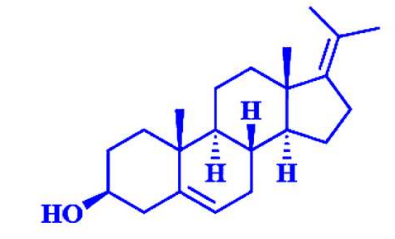

20-methyl-pregna-5,17-dien-3ß-ol<smiles>CC(O)[C@H]1CC[C@H]2[C@H]3CCC4=CC(=O)CC[C@]4(C(=O)O)C3=CC[C@@]12C</smiles>

Pregna-4,9 (11)-dien-20-ol-3-on-19-oic acid

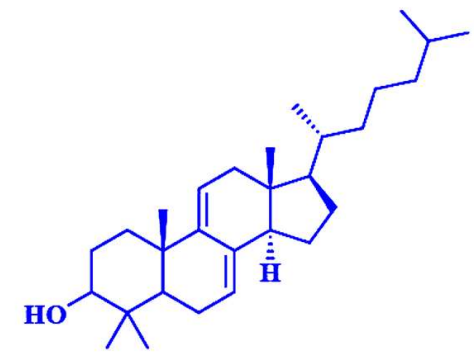

4,4-Dimethylcholesta-7,9(11)-dien-3-ol

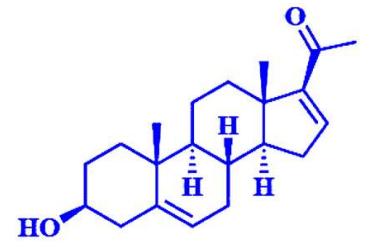

16-Dehydropregnenolone<smiles>CC1=C(C)C2=CC(=O)c3c(c(O)c4occ(C)c4c3O)C2CC1</smiles>

Ajuforrestine A

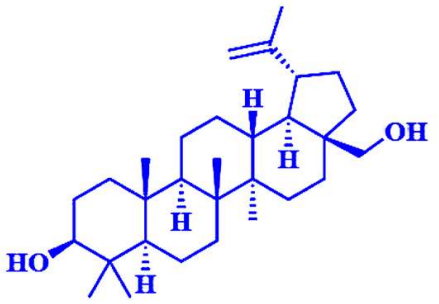

Betulin

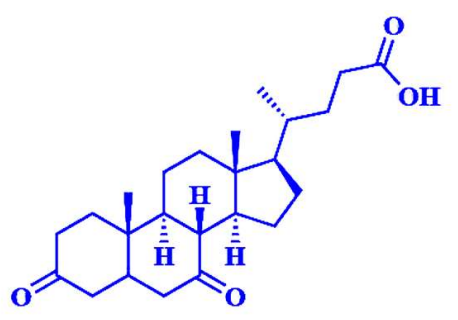

3,7-Dioxocholan-24-oic acid

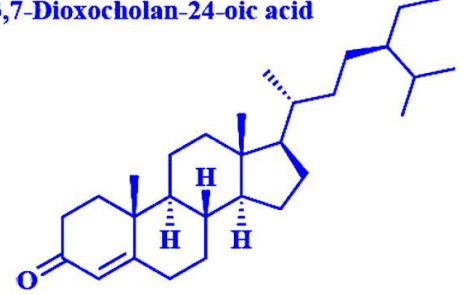

Stigmast-4-en-3-one

Figure 5: Structure of compounds identified from the root extract of the medicinal plant, A. turkestanica (Mamadalieva et al., 2013).

\section{Conclusion}

The medicinal plant $A$. turkestanica, an endemic species of the Boysun Pamir-Alay Mountains, contains exdesteroid compounds. These biologically active exdisteroid compounds are used in traditional medicine and pharmaceuticals. In the flora of Uzbekistan, $A$. turkestanica is a medicinal plant, rich in phytoecdisteroid raw materials. Due to the biological, pharmacological, medicinal properties of the plant $A$. turkestanica, its widespread use in pharmaceuticals, the plant is on the verge of extinction, which leads to limited access to biologically active substances from the plant. Therefore, it is necessary to propagate the plant $A$. turkestanica, to create its natural plantations. It is necessary to improve the methods of obtaining biologically active substances from plants by biotechnological methods, i.e., by endophytic micro-organisms.

\section{Conflict of interest}

The authors declare that there are no conflicts of interest in the course of conducting the research. All the authors had final decision regarding the manuscript and decision to submit the findings for publication.

\section{References}

Abdukadyrov, I.T.; Khodzhaeva, M.A.; Turakhodjaev, M.T. and Mamatkhanov, A.U. (2004). Carbohydrates from Ajuga turkestanica. Chemistry of Natural Compounds, 40:85-86.

Abdukadyrov, I.T.; Yakubova, M.R.; Nuriddinov, Kh.R.; Mamatkhanov, A.U. and Turakhodjaev, M.T. (2005). Ecdysterone and turkesterone in Ajuga turkestanica determined by HPLC. Chemistry of Natural Compounds, 41:475-476.

Adler, J. H. and Grebenok, R. J. (1995). Occurrence, biosynthesis, and putative role of ecdysteroids in plants. Crit. Rev. Biochem. Mol. Biol., 34:253-264.

Ahmad, K.S.; Kayani, W.K.; Hameed, M.; Ahmad, F. and Nawaz, T. (2012). Floristic diversity and ethnobotany of senhsa, district Kotli, Azad Jammu and Kashmir (Pakistan). Pak. J. Bot., 44:195-201.

Ahmad, K.S. and Habib, S. (2014). Indigenous knowledge of some medicinal plants of Himalaya Region, Dawarian Village, Neelum Valley, Azad Jammu and Kashmir, Pakistan. Univ. J. Plant Sci., 2(2):40-47.

Akbay, P.; Çalis, I.; Heilmann, J. and Sticher, O. (2003a). New stigmastane sterols from Ajuga salicifolia. J. Nat. Products, 66:461-465. 
Akbay, P.; Çalis, I.; Heilmann, J. and Sticher, O. (2003b). Ionone, iridoid and phenylethanoid glycosides from Ajuga salicifolia. Z. Naturforsch C., 58:177-180.

Akbay, P.; Gertsch, J.; Çalis, I.; Heilmann, J.; Zerbe, O. and Sticher, O. (2002). Novel antileukemic sterol glycosidesfrom Ajuga salicifolia. Helv. Chim. Acta., 85:1930-1942.

Alekseeva, L.I. (2004). Ecdysone 20-monooxygenaseactivity of cytochrome P 450 in Ajuga reptans L. plantsand cell culture. Appl. Biochem. Microbiol., 40:135-139.

Alekseeva, L.I.; Volodin, V.V.; Luksha, V.G. and Lafont, R. (1999). Ecdysteroid acetate from A. reptans. Chem. Nat. Compd., 35:607-610.

Alexeeva, L.I.; Volodin, V.V.; Teteruk, L.V.; Luksha, V.G. and Lafont, R. (1998). Abstracts of posters. International Conference on Natural Products and Physiologically Active Substances (ICNPAS-98). Novosibirsk, pp:187.

Aliotta, G. and Pollio, A. (1994). Useful plants in renal therapy according to Pliny the elder. Am. J. Nephrol., 14:399-411.

Ali-Shtayeh, M.S.; Yaniv, Z. and Mahajna, J. (2000). Ethnobotanical survey in the Palestinian area: A classification of the healing potential of medicinal plants. J. Ethnopharmacol., 73:221-232.

Ali, T., Zahida, S. and Rabiah B. (2019). A review on phytochemical and ethnopharmacological studies of Ajuga Bracteosa Wall. Ex Benth. Journal of Drug Delivery and Therapeutics, 9(2):489-492.

Aly, R.; Ravid, U.; Abu-Nassar, J.; Botnick, I.; Lebedev, G.; Gal, S.; Ziadna, H.; Achdari, G.; Smirov, E.; Meir, A. and Ghanim, M. (2011). Biological activity of natural phytoecdysteroids from Ajuga iva against the sweet potato whitefly Bemisia tabaci and the persea mite Oligonychus perseae. Pest Manage Sci., 67:1493-1498.

Atay, I.; Kirmizibekmez, H.; Kaiser, M.; Akaydin, G.; Yesilada, E. and Tasdemir, D. (2016). Evaluation of in vitro antiprotozoal activity of Ajuga laxmannii and its secondary metabolites. Pharm. Biol., 54:18081814 .

Azizan, J.; Fallah-Bagher-Shaidaei, H.; and Kefayati, H. (2002). Chemical constituents of the essential oil of Ajuga chamaepitys growing in Iran. Journal of Essential Oil Research. 14:344-345.

Baltaev, U. A. (2000). Phytoecdysteroids: Structure, source and biosynthesis in plants. Russ. J. Bioorg. Chem., 26:799-831.

Báthori, M. and Pongracz, Z. (2005). Phytoecdysteroids from isolation to their effects in humans. Curr. Med. Chem., 12:153-172.

Bathori, M.; Toth, N.; Hunyadi, A.; Marki, A. and Zador, E. (2008). Phytoecdysteroids and anabolicandrogenic steroids structure and effects on humans. Curr. Med. Chem., 15:75-91.

Baytop, T. (1984). Therapy with medicinal plants (Past and Present); Istanbul University Publications, Istanbul, 298:416.

Beauchamp, P.S.; Bottini, A.T.; Caselles, M.C.; Dev, V.; Hope, H.; Larter, M.; Lee, G.; Mathela, C. S.; Melkani, A.B.; Millar, P.D.; Miyatake, P.D.; Pant, A.K.; Raffel, R.J.; Sharma, V.K. and Wyatt, D. (1996). Neo-clerodane diterpinoids from Ajuga parviflora. Phytochemistry, 43:827-834.

Bellakhdar, J.; Claisse, R.; Fleurentin, J. and Younos, C. (1991). Repertory of standard herbal drugs in the Moroccan pharmacopoeia. J. Ethnopharmacol., 35:123-143.

Belles, X. and Piulachs, M. D. (2015). Ecdysone signalling and ovarian development in insects: From stem cells to ovarian follicle formation. Biochim. Biophys. Acta, 1849:181-186.
Ben Jannet, H.; Chaari, A.; Bakhrouf, A. and Mighri. Z. (2006). Structureantibacterial activity relationship of secondary metabolites from Ajuga pseudoiva Rob. leaves. Nat. Prod. Res., 20:299-304.

Ben Jannet, H.; Chaari, A.; Mighri, Z.; Martin, M.T. and Loukaci, A. (1999). Neoclerodane diterpenoids from Ajuga pseudoiva leaves. Phytochemistry, 52:1541-1545.

Bennaghmouch, L.; Hajjaji, N.; Zellou, A. and Cherrah, Y. (2001). Pharmacological study of Ajuga iva. [French]. Ann. Pharmaceut. Francais., 59:284.

Bergamasco, R. and Horn, D.H.S. (1983). Distribution and role of insect hormones in plants. In: Endocrinology of insects. New York: Alan R. Liss, Inc., pp:627-654.

Bnouham, M.; Mekhfi, H.; Legssyer, A. and Ziyyat, A. (2002). Medicinal plants used in the treatment of diabetes in Morocco. Int. J. Diabetes Metab., 10:33-50.

Bondì, M.L.; Al-Hillo, M.R.Y.; Lamara, K.; Ladjel, S.; Bruno, M.; Piozzi, F. and Simmonds, M.S. J. (2000). Occurrence of the antifeedant 14, 15dihydroajugapitin in the aerial parts of Ajuga iva from Algeria. Biochem. Syst. Ecol., 2:1023-1025.

Bozov, P.I.; Papanov, G.Y.; Malakov, P.Y.; de la Torre, M.C. and Rodríguez, B. (1993). A clerodane diterpene from Ajuga salicifolia. Phytochemistry, 34:1173-1175.

Bremner, P.D.; Simmonds, M.S.J.; Blaney, W.M. and Veitch, N.C. (1998). Neoclerodane diterpenoid insect antifeedants from Ajuga reptans cv Catlins Giant. Phytochemistry, 47:1227-1232.

Calcagno, M.P.; Camps, F.; Coll, J.; Melé, E. and Sánchez, Baeza, F. (1996). New phytoecdysteroids from roots of Ajuga reptans varieties. Tetrahedron, 52:10137-10146.

Camps, F. and Coll, J. (1993). Insect allelochemicals from Ajuga plants. Phytochemistry, 32:1361-1370.

Camps, F.; Coll, J. and Cortel, A. (1981a). Allelochemicals on insects isolated from Ajuga plants (Lamiaceae). Rev. Latinoam. Quím., 12:81-87.

Camps, F.; Coll, J. and Cortel, A. (1981b). Two new clerodane diterpenoids from Ajuga reptans. Chem. Lett., 7:1093-1096.

Camps, F.; Coll, J. and Cortel, A.A. (1982a). New-clerodane diterpenoids from Ajuga iva (Lamiaceae). Chem. Lett., 7:1053-1056.

Camps, F.; Coll, J. and Dargallo, O. (1984a). Neo-clerodane diterpenoids from Ajuga pseudoiva. Phytochemistry, 23:387-389.

Camps, F.; Coll, J. and Dargallo, O. (1984b). Neo-clerodane diterpenoids from Ajuga chamaepitys. Phytochemistry, 23:2577-2581.

Camps, F.; Coll, J.; Cortel, A. and Messeguer, A. (1979). Ajuga reptansin: A new diterpenoid from Ajuga reptans. Tetrahedron Lett., 20:1709-1712.

Camps. F.; Coll, J. and Cortel, A.A. (1982b). 29-Norsengosterone and 29norcyasterone, new C-28 phytoecdysteroids from Ajuga reptans (Lamiaceae). Chem. Lett., 7:1313-1316.

Cantrell, C.L.; Rajab, M.S.; Franzblau, S.G.; Fronczek, F.R. and Fisher, N.H. (1999). Antimycobacterial ergosterol-5, 8-endoperoxide from Ajuga remota. Planta. Med., 65:732-734.

Castro, A.; Coll, J.; Tandron, Y.A.; Pant, A.K. and Mathela, C.S. (2008). Phytoecdysteroids from Ajuga macrosperma var. breviflora roots. J. Nat. Prod., 71:1294-1296.

Catalan, R.E.; Martinez, A.M.; Aragones, M.D.; Miguel, B.G.; Robles, A. and Godoy, J.E. (1985). Alterations in rat lipid metabolism following ecdysterone treatment. Comp Biochem Physiol [B], 81(3):771-775. 
Chan, Y.Y.; Wu, T.S.; Kuoh, C.S. and Damu, A.G. (2005). A new phytoecdysteroid from Ajuga taiwanensis. Chem. Pharm. Bull., 53:836-838.

Chandel, S. and Bagai, U. (2010). Antiplasmodial activity of Ajuga bracteosa against Plasmodium berghei infected BALB/c mice. Indian J. Med. Res., 131:440-444.

Chen, H.; Tan, R.X.; Liu, Z.L.; Zhang, Y. and Yang, L. (1996a). Antibacterial neo-clerodane diterpenoids from Ajuga lupulina. J. Nat. Prod., 59:668-670.

Chen, H.; Tan, R.X.; Liu, Z.L.; Zhao C.Y. and Sun, J. (1997). A clerodane diterpene with antibacterial activity from Ajuga lupulina. Acta Cryst. C., 53:814-816.

Cheng, D.; Yousef, G.G.; Grace, M.H.; Rogers, R.B.; Gorelick-Feldman, J. and Raskin, I. (2008). In vitro production of metabolism-enhancing phytoecdysteroids from Ajuga turkestanica. Plant Cell Tiss Organ Cult., 93:73-83.

Chenni, A.; Yahia, D.A.; Boukortt, F.O.; Prost, J.; Lacaille Dubois, M.A. and Bouchenak, M. (2007). Effect of aqueous extract of Ajuga iva supplementation on plasma lipid profile and tissue antioxidant status in rats fed a high-cholesterol diet. J. Ethnopharmacol., 109:207-213

Chou, W.S. and Lu, H.S. (1980). In progress in ecdysone research, ed. by J.A. Hoffmann (Elsevier/North Holland Biomed. Press, Amsterdam), pp:281.

Coll, J.; Tandrón, Y.A. and Zeng, X.N. (2007). New phytoecdysteroids from cultured plants of Ajuga nipponensis Makino. Steroids, 72:270-277.

Darvas, B.; Coll, J. and Polgar, A. (1998). XIIIth Ecdysone Workshop, Jena, pp:52.

David, E. Zaurov; Igor V. Belolipov; Anvar G. Kurmukov; Ishenbay S. Sodombekov; Anarbek A. Akimaliev Sasha W. and Eisenman S. Eisenman (2013). Medicinal Plants of Central Asia: Uzbekistan and Kyrgyzstan, (C)The Editor Springer., pp:27.

Diana Meimei Cheng (2010). Phytoecdysteroid accumulation in plants and bioactivities in animal models DISSERTATION submitted in partial fulfillment of the requirements for the degree of Doctor of Philosophy in Natural Resources and Environmental Sciences with a minor in Russian, East European, and Eurasian Studies in the Graduate College of the University of Illinois at Urbana-Champaign, Urbana, Illinois. pp:4-24

Dinan, L. (1992). The analysis of phytoecdysteroids in single (preflowering stage) specimens of fat hen, Chenopodium album. Phytochem. Anal., 3:132-138.

Dinan, L. (2001). Phytoecdysteroids: Biological aspects. Phytochemistry, 57:325-339.

Dinan, L. and Lafont, R. (2006). Effects and applications of arthropod steroid hormones (ecdysteroids) in mammals. J. Endocrinol., 191:1-8.

Dinan, L. and Savchenko, T. ( 2001). Whiting, P. On the distribution of phytoecdysteroids in plants. Cell. Mol. Life Sci., 58:1121-1132.

Dumas, M.; Gondran, C.; Barre, P.; Sougrat, R.; Verbavatz, J.M.; Heusele, C.; Schnebert, S. and Bonte, F. (2002). Effect of an Ajuga turkestanica extract on aquaporin 3 expression, water flux, differentiation and barrier parameters of the human epidermis. Eur. J. Dermatol., 12:25-26.

Dumas, M.; Sadick, N.S.; Noblesse, E.; Juan, M.; Lachmann, Weber, N.; BouryJamot, M.; Sougrat, R.; Verbavatz, J.M.; Schnebert, S. and Bonte, F. (2007). Hydrating skin bystimulating biosynthesis of aquaporins. J. Drugs Dermatol., 6(6):20-24.
Eddouks, M.; Ouahidi, M.L.; Farid, O.; Moufid, A.; Khalidi, A. and Lemhadri, A. (2007). The use of medicinal plants in the treatment of diabetes in Morocco. Phytotherapie., 5:194-203.

El-Hilaly, J.; Israili, Z.H. and Lyoussi, B. (2004). Acute and chronic toxicological studies of Ajuga iva in experimental animals. J. Ethnopharmacol., 91:43-50.

Fekete, G.; Polgár, L.; Báthori, M.; Coll, J. and Darvas, B. (2004). Peros efficacy of Ajuga extracts against sucking insects. Pest Manag. Sci., 60: 1099-1104.

Ganiev Sh. G.; Khamidkhodjaev S. A.; Djuharova M. X. and Saatov Z. (1990). Ajuga turkestanica from Baysuntay (Baysun mountin). Uzbek Biology Journal, pp:30-32 .

Gauthier, C.; Legault, J.; Lavoie, S.; Rondeau, S.; Tremblay, S. and Pichette, A. (2009). Synthesis and cytotoxicity of bidesmosidic betulin and betulinic acid saponins. Journal of Natural Products, 72:72-81.

Githinji, C.W. and Kokwaro, J.O. (1993). Ethnomedicinal study of major species in the family Labiatae from Kenya. J. Ethnopharmacol., 39:197-203

Gorelick-Feldman, J.; Cohick, W. and Raskin, I. (2010). Ecdysteroids elicit a rapid $\mathrm{Ca}^{2+}$ flux leading to Akt activation and increased protein synthesis in skeletal muscle cells. Steroids, 75:632-637

Gorelick-Feldman, J.; Maclean, D.; Ilic, N.; Poulev, A.; Lila, M.A. and Cheng, D. (2008). Phytoecdysteroids increase protein synthesis in skeletal muscle cells. J. Agric. Food. Chem., 56:3532-3537.

Grace, M.H.; Cheng, D.M.; Raskin, I. and Lila, M.A. (2008). Neo-clerodane diterpenes from Ajuga turkestanica. Phytochemistry Letters, 1:81-84.

Grebenok, R. J. and Adler, J. H. (1991). Ecdysteroid distribution during development of spinach. Phytochemistry, 33:341-347.

Hanaya, R.; Sasa, M.; Ishihara, K.; Akimitsu, T.; Iida, K.; Amano, T.; Serikawa, T.; Arita, K. and Kurisu, K. (1997). Antiepileptic effects of 20hydroxyecdysone on convulsive seizures in spontaneously epileptic rats. Jpn. J. Pharmacol., 74(4):331-335.

Hernández, A.; Pascual, C.; Sanz, J. and Rodríguez, B. (1982). Diterpenoids from Ajuga chamaepitys: two neoclerodane derivatives. Phytochemistry, 21:2909-2911.

Hetru, C. and Horin, D.H.S. (1980). Phytoecdysteroids and zooecdysteroids In: Progress in ecdysone research. Hoffmann JA, ed., Developments in endocrinology. Elsevier/North-Holland, Amsterdam, Vol.7, pp:13-28.

Hikino, H.; Hikino, Y.; Nomoto, K. and Takemoto, T. (1968). Cyasterone, an insect meta-morphosing substance fom Cyathula capitata: structure. Tetrahedron, 24:4895-4906.

Hussain, J.; Begum, N.; Hussain, H.; Khan, F. U.; Rehman, N. U.; Al-Harrasi, A. and Ali, L. (2012). Ajuga nane: A new phenolic compound from Ajuga bracteosa. Nat. Prod. Commun., 7:615-616.

Ikan, R. and Ravid, U. (1971). The isolation and identification of ecdysterone from Ajuga iva. Planta Med., 20:33-35.

Ikan, R. and Ravid, U. (1971). The isolation and identification of cyasterone from Ajuga chia (Labiatae). Phytochemistry, 10:1659-1661.

Imai, S.; Murata, E.; Fujioka, S.; Koreeda, M. and Nakanishi, K. (1969a). Structure of Ajugasterone C, a phytoecdysone with an 11-hydroxy-group. J. Chem. Soc. Chem. Commun., pp:546-547. 
Imai, S.; Toyosato, T.; Sakai, M.; Soto, Y. and Fujioka, S. (1969b). Screening results of plants for phytoecdysones. Chem. Pharm. Bull., 17:335-339.

Israili, Z. H. and Lyoussi, B. (2009). Ethnopharmacology of the plants of genus Ajuga. Pak. J. Pharm. Sci., 22:425-462.

Jan, M.; Singh, S.; Kaloo, Z.A. and Maqbool, F. (2014). Medicinal importance of Ajuga bracteosa Wall ex Benth: A review. Int. J. Adv. Res., 2(1):389-394.

Jakovljevic, D.Z.; Vasić, S.M.; Stanković, M.S.; Čomić, L.R. and Topuzović, M.D. (2015). Secondary metabolite content and in vitro biological effects of Ajuga chamaepitys (L.) Schreb. subsp. chamaepitys. Arch. Biol. Sci., 67:1195-1202.

Jouad, H.; Haloui, M.; Rhiouani, H.; El-Hilaly, J. and Eddouks, M. (2001). Ethnobotanical survey of medicinal plants used for the treatment of diabetes, cardiac and renal diseases in the north centre region of Morocco (Fez Boulemane). J. Ethnopharmacol., 77:175-182.

Kaithwas, G.; Gautam, R.; Jachak, S.M. and Saklani, A. (2012). Antiarthritic effects of Ajuga bracteosa Wall ex Benth. in acute and chronic models of arthritis in albino rats. Asian Pac. J. Trop. Biomed., 2(3): 185-188.

Khan, P.M.; Ahmad, S.; Nawaz, H.R.; Ullah, N. and Malik, A. (1999a). New acetylated quinols from Ajuga parviflora. Fitoterapia, 70:229-232.

Kholodova, Yu. D. (2001). Phytoecdysteroids: Biological effects, application in agriculture and complementary medicine. Ukr Biokhim Zh, 73:21-29.

Kholodova, Yu.D.; Tugai, V.A. and Zimina, V.P. (1997). Effect of vitamin $\mathrm{D}_{3}$ and 20-hydroxyecdysone on the content of ATP, creatine phosphate, carnosine and $\mathrm{Ca}^{2+}$ in skeletal muscles. Ukr Biokhim Zh, 69(3):3-9.

Knafagy, S.M.; Sabri, N.N.; El-Sebakny, N.; Blessington, B. and Asaad, A. (1979). Planta Med., 35:184.

Kokwaro, J.O. (1993). Medicinal plants of East Africa, $2^{\text {nd }}$ ed. East Africa Literature Bureau/Kenya Literature Bureau, Kampala, Nairobi, Dar Es Salaam, pp:368

Koreeda, M.; Nakanishi, K. and Goto, M. (1971). Ajugalactone, an insect moulting inhibitor as tested by the Chilo dipping method. J. Amer. Chem. Soc., 92:7512-7513

Kosovskii, M.I.; Syrov, V.N.; Mirakhmedov, M.M.; Katkova, S.P. and Khushbaktova, Z.A. (1989). The effect of nerobol and ecdysterone on insulindependent processes linked normally and in insulin resistance. Probl. Endokrinol., (Mosk), 35:77-81.

Kotenko, L.D.; Yakubova, M.R.; Mamatkhanov, U.; Saatov, Z. and Turakhozhaev, M.T. (1993). Iridoids of Ajuga turkestanica and their quantitative determination. Chem. Nat. Compd., 29:606-607.

Kubo, I.; Klocke, J.A.; Ganjian, I.; Ichkawa, N. and Matsumoto, T. (1983). Efficient isolation of phytoecdysones from Ajuga plants by highperformance liquid chromatography and droplet counter-current chromatography. J. Chromatog., 257:157-161.

Kurmukov, A.G. and Ermishina, O.A. (1991). The effect of ecdysterone on experimental arrhythmias and changes in the hemodynamics and myocardial contractility induced by coronary artery occlusion. Farmakol Toksikol, 54(1):27-29.

Kurmukov, A.G. and Kurmukova, N.A. (1992). Influence of ecdysterone on prenatal hypertrophy, caused by infringement of placental-uterine circulation. In: Eksperimentalnaya farmalogiya klinishi: "Tezisui dokladov". Vinnytsia, Kiev, pp:42-43.
Kutepova, T.A.; Syrov, V.N.; Khushbaktova, Z.A. and Saatov, Z. (2001). Hypoglycemic activity of the total ecdysteroid extract from Ajuga turkestanica. Pharm. Chem. J. (Khim Farm Zhur), 35:608-609.

Lafont, R. (1998). Phytoecdysteroids in the world flora: Diversity, distribution, biosynthesis, and possible ecological significance. Russ. J. Plant Physiol., 45:276-295.

Lafont, R. and Dinan, L. (2003). Practical uses for ecdysteroids in mammals including humans: an update. J. Insect Sci., 3:1-30.

Leena Taha-Salaime; Rachel Davidovich-Rikanati; Asaf Sadeh; Jackline AbuNassar; Sally Marzouk-Kheredin; Yahyaa Yahyaa; Mwafaq Ibdah; Murad Ghanim; Efraim Lewinsohn; Moshe Inbar and Radi Aly (2019). Phytoecdysteroid and clerodane content in three wild Ajuga Species in Israel Cite This: ACS Omega, 4:2369-2376

Makhsudov, M.S. and Saatov, Z. (1995). 1st International Conference "Probleme of Bioorganic Chemistry." Namangan, pp:20.

Mamatkhanov, A.U.; Yakubova, M.R. and Syrov, V.N. (1998). Isolation of turkesterone from the epigeal part of Ajuga turkestanica and its anabolic activity. Chem. Nat. Compd., 34(2):150-154.

Marc, E.B.; Nelly, A.; Annick, D.D. and Frederic, D. (2008). Plants used as remedies antirheumatic and antineuralgic in the traditional medicine of Lebanon. J. Ethnopharmacol., 120:315-334.

Marcus Michael Lawrence (2012). Ajuga turkestanica as a countermeasure against Sarcopenia and Dynapenia submitted to the Graduate School, Appalachian State University in partial fulfillment of the requirements for the degree of MASTER OF SCIENCE August Department of Health, Leisure and Exercise Science, pp:49-76.

Matsuda, H.; Kawaba, T. and Yamamoto, Y. (1970). Pharmacological studies of insect metamorphotic steroids. Nihon Yakurigaku Zasshi, 66:551-563

Matsuoka, T.; Imai, S.; Sakai, M. and Kamada, M. (1969). Studies on phytoecdysones: A review of our works. Annual Report of the Takeda Research Laboratory, 28:221-271.

Mirzaev, I.R.; Syrov, V.N.; Khrushev, S.A. and Iskanderova, S.D. (2000). Effect of ecdystene on parameters of the sexual function under experimental and clinical conditions. Eksp. Klin. Farmakol., 63(4): 35-37.

Newman, L.F. (1948). Some notes on the pharmacology and therapeutic value of folk-medicine, II. Trans. Folk-Lore Soc., 59:145-156.

Nilufar Z. Mamadalieva; Mahmoud Z. El-Readi; Elisa Ovidi; Mohamed L. Ashour; Razan Hamoud; Shamansur S. Sagdullaev; Sakhnoza S. Azimova; Antonio Tiezzi and Michael Wink (2013). Antiproliferative, antimicrobial and antioxidant activities of the chemical constituents of Ajuga turkestanica. Phytopharmacology, 4:(1):1-18

Njoroge, G.N. and Bussmann, R.W. (2006). Diversity and utilization of antimalarial ethnophytotherapeutic remedies among the Kikuyus (Central Kenya). J. Ethnobiol. Ethnomed., 2:8.

Ogawa, S.; Nishimoto, N. and Matsuda, H. (1974). Pharmacology of ecdysones in verterbrates. In: Burdette WJ, editor. Invertebrate Endocrinology and Hormonal Heterophyly. Berlin: Springer, pp:341-344.

Osipova, S.O.; Islamova, Zh.I.; Syrov, V.N.; Badalova, N.S. and Khushbaktova, Z.A. (2002). Ecdysten in the treatment of giardiasis. Med. Parazitol., 1:29-33.

Ramazanov, N. S. (2005). Phytoecdysteroids and other biologically active compounds from plants of the genus Ajuga. Chem. Nat. Comp., 41:361-369 
Ramazanov, N. Sh. and Syrov, N.N. (2006). Synthesis of cyasteronylthiocarbamate derivatives. Chem. Nat. Prod., 42:558-561.

Rani, R.; Khan, M.A.; Kayani, W.K.; Ullah, S.; Naeem, I. and Mirza, B. (2017). Metabolic signatures altered by in vitro temperature stress in Ajuga bracteosa Wall. ex. Benth. Acta Physiol. Plant, pp:39.

Ray, D. P.; Dutta, D.; Srivastava, S.; Kumar, B. and Saha, S. (2012). Insect growth regulatory activity of Thevetia nerifolia Juss. against Spodoptera litura (Fab.). J. Appl. Bot. Food Qual., 85:212-215.

Riaz, N.; Malik, A.; Aziz-ur-Rehman.; Nawaz, S.A.; Muhammad, P. and Choudhary, M.I. (2004). Cholinesterase-inhibiting withanolides from Ajuga bracteosa. Chem. Biodivers., 1:1289-1295.

Rodriguez-Hahn, L.; Esquivel, B. and Cárdenas, J. (1994). Clerodane diterpenoids in Labiatae. Prog. Chem. Nat. Prod., 63:107-196.

Rozengurt, E. (2007). Mitogenic signaling pathways induced by G proteincoupled receptors. J. Cell Physiol., 213:589-602.

S. Hemadri Reddy*; Aisha Khalid AL-Hinai; Hajer Hafed AL-Yaqoobi and Fatima Jafar AL-Ajmi (2016). Phytochemical analysis, antimicrobial screening and hypoglycemic effect of some selected medicinal plant extract from oman Journal of Experimental Biology and Agricultural Sciences, 4:(2)218-224.

Saatov, Z.; Agzamkhodzhaeva, D.A. and Syrov, V.N. (1999). Distribution of phytoecdysteroids in plants of Uzbekistan and the possibility of using drugs based on them in neurological practice. Chemistry of Natural Compounds., 35:186-191.

Saatov, Z.; Usmanov, B.Z. and Abubakirov, N.K. (1977). Phytoecdysones from Ajuga turkestanica. IV. Chemistry of Natural Compounds., 13:359.

Sabri, N.N.; Asaad, A. and Khafagy, S.M. (1981). Isolation of four ecdysones from Ajuga iva roots and a rapid semiquantitative method for ecdysone determination. Planta Med., 42:293-295.

Shen, X.; Isogai, A.; Furihata, K.; Sun, H. and Suzuki, A. (1993). Two neo-clerodane diterpenoids from Ajuga macrosperma. Phytochemistry, 33:887-889.

Shen, X.; Isogai, A.; Furihata, K.; Sun, H. and Suzuki, A. (1993). Neo-clerodane diterpinoids from Ajuga macrosperma and Ajuga pantantha. Phytochemistry, 34:1091-1094.

Sher, H. and Al-yemeni, M. (2011). Economically and ecologically important plant communities in high altitude coniferous forest of Malam Jabba, Swat, Pakistan. Saudi J. Biol. Sci., 18(1):53-61.

Shimomura, H.; Sashida, Y. and Ogawa, K. (1989a). Neo-clerodane diterpenes from Ajuga nipponensis. Chem. Pharm. Bull., 37:354-357.

Shimomura, H.; Sashida, Y. and Ogawa, K. (1989b). Neo-clerodane diterpenes from Ajuga ciliata var. villosior. Chem. Pharm. Bull., 37:988-992.

Speranza, A. (2010). Into the world of steroids: A biochemical 3 keep in touch3 in plants and animals. Plant Signaling Behav., 5:940-943.

Syrov, V. N. (1994). Phytoecdysteroids: Their biological effects in the body of higher animals and the outlook for their use in medicine. Eksp Klin Farmakol., 57:61-66.

Syrov, V. N. (2001). Comparative experimental investigations of anabolic activity of phytoecdysteroids and steranabol. Pharm. Chem. J., 34:193-197.

Syrov, V.N. and Khushbaktova, Z.A. (2001). Experimental study of pharmacotherapeutic effect of phytoecdysteroids and nerobol in toxic liver damage. Eksp Klin Farmakol., 64:56-58.
Syrov, V.N. Kurmukov, A.G. and Sakhibov, A.D. (1978). Effect of turkesterone and nerobol on the activity of the protein synthesizing system of mouse liver. Vopr. Med. Khim., 24:456-460.

Syrov, V.N.; Khushbaktova, Z.A. and Nabiev, A.N. (1992a). An experimental study of the hepatoprotective properties of phytoecdysteroids and nerobol in carbon tetrachlorideinduced liver lesion. Eksp. Klin. Farmakol., 55:61-65.

Syrov, V.N.; Khushbaktova, Z.A.; Abzalova, M.Kh. and Sultanov, M.B. (1983). Hypolipidemic and antiatherosclerotic properties of phytoecdysteroids. Doklady Akademii Nauk UzSSR., 9:44-45.

Syrov, V.N.; Nabiev, A.N. and Sultanov, M.B. (1986). Action of phytoecdysteroids on the bile-secretory function of the normal liver and in experimental hepatitis. Farmakol. Toksikol., 49:100-103.

Syrov, V.N.; Nabiev, A.N.; Khushbaktova, Z.A.; Zakhidov, U.V.; Maksudov, M.S. and Saatov, Z. (1998). Hepatoprotector activity of iridoid glycosides with respect to heliotrine-induced acute toxic liver damage in mice. Pharm. Chem. J., 33(8):410-412.

Syrov, V.N.; Nasyrova, S.S. and Khushbaktova, Z.A. (1997). The results of experimental study of phytoecdysteroids as erythropoiesis stimulators in laboratory animals. Eksp. Klin. Farmakol., 60:41-44.

Syrov, V.N.; Tashmukhamedova, M.A.; Khushbaktov, Z.A.; Mirtalipov, D.T. and Mamatkhanov A.U. (1992b). Effect of phytoecdysteroids and nerobol on parameters of carbohydrate and lipid metabolism and phospholipid spectrum of liver mitochondrial membrane in experimental diabetes mellitus of rats. Ukr. Biokhim. Zh., 64:61-67.

Tahraoui, A.; El-Hilaly, J.; Israili, Z.H. and Lyoussi, B. (2006). Ethnopharmacological survey of plants used in the traditional treatment of hypertension and diabetes in south-eastern Morocco (Errachidia province). J. Ethnopharmacol., 110:105-117.

Takahashi, H. and Nishimoto, N. (1992). Antidiabetic agents containing ecdysterone or inokosterone. J. Patent, 4:125-135.

Takasaki, M.; Tokuda, H.; Nishino, H. and Konoshima, T. (1999). Cancer chemopreventive agents (antitumorpromoters) from Ajuga decumbens. J. Nat. Prod., 62:972-975

Takasaki, M.; Yamauchi, I.; Haruna, M. and Konoshima, T. (1998). New glycosides from Ajuga decumbens. J. Nat. Prod., 61:1105-1109.

Tashmukhamedova, M.A.; Almatov, K.T. Syrov, V.N.; Sultanov, M.B. and Abidov, A.A. (1986). Comparativestudy of the effect of ecdysterone, turkesterone andnerobol on the function of rat liver mitochondria in experimental diabetes. Vopr. Med. Khim., 32:24-28.

Tashmukhamedova, M.A.; Almatov, K.T.; Khushbaktova, Z.A. and Syrov, V.N. (1986). Effect of phytoecdysteroids and steranobols on the activity and stability of membranebound enzymes of liver mitochondria in experimental hepatitis. Vopr. Med. Khim., 32:81-84.

Tashmukhamedova, M.A.; Almatov, K.T.; Syrov, V.N.; Sultanov, M.B. and Abidov, A.A. (1985). Effect of phytoecdisteroids and anabolic steroids on livermitochondrial respiration and oxidative phosphorylation in alloxan diabetic rats. Nauchnye. Doki. Vyss. Shkoly. Biol. Nauki., 9:37-39.

Toth, N.; Szabo, A.; Kacsala, P.; Heger, J. and Zador, E. (2008). 20 Hydroxyecdysone increases fiber size in a muscle-specific fashion in rat. Phytomedicine, 15:691-698.

Trenin, S. and Volodin V.V. (1999). 20-hydroxyecdysone as a human lymphocyte and neutrophil modulator: in vitro evaluation. Archives of Insect Biochemistry and Physiology, 41,156-161. 
Tsuji, K.; Shibata, J.; Okada, M. and Inaoka, Y. (1999). Blood flow amountimproving agent comprising steroid derivative and cosmetic using same. US Patent 5976515 to Pola Chemical Industries, Inc.

Ulukanli, Z.; Ulukanli, S.; Ozbay, H.; Ilcim, A. and Tuzcu, M. (2005). Antimicrobial activities of some plants from the eastern Anatolia region of Turkey. Pharm. Biol., 43:334-339.

Usmanov, B.Z.; Gorovits, M.B. and Abubakirov, N.K. (1971). Phytoecdysones from Ajuga turkestanica. Chemistry of Natural Compounds, 7:520.

Usmanov, B.Z.; Gorovits, M.B. and Abubakirov, N.K. (1973). Phytoecdysones from Ajuga turkestanica. II. Chemistry of Natural Compounds, 9:125-126.

Usmanov, B.Z.; Rashkes, Y.V. and Abubakirov, N.K. (1978). Phytoecdysones of Ajuga turkestanica. VI. 22- Acetylcyasterone from Ajuga turkestanica. Chemistry of Natural Compounds, 14:175-178.

Usmanov, B.Z.; Saatov, Z. and Abubakirov, N.K. (1977). Phytoecdysones from Ajuga turkestanica. V. Chemistry of Natural Compounds, 13:595.

Usmanov, V.Z.; Gorovits, M.B. and Abubakirov, N.K. (1974). Phytoecdysterones from Ajuga turkestanica. Chem. Nat. Compd. (Khim Prir Soedin), 4:466-470.

Usmanov, V.Z.; Gorovits, M.B. and Abubakirov, N.K. (1975). Phytoecdyones from Ajuga turkestanica III. The structure of turke. Chem. Nat. Compd. (Khim Prir Soedin), 11:484-487.

Usmanov, V.Z.; Gorovits, M.B. and Abubakirov, N.K. (1978). 22Acetylcyasterone from Ajuga turkestanica. Chem. Nat. Compd. (Khim Prir Soedin), 2:215-219.

Volodin, V.; Chadin, I.; Whiting, P. and Dinan. L. (2002). Screening plants of European North-East Russia for ecdysteroids. Biochemical Systematics and Ecology, 30(6):525-578.
Wessner, M.; Champion, B.; Girault, J-P.; Kaouadji, N.; Saidi, B. and Lafont, R. (1992). Ecdysteroids from Ajuga iva. Phytochemistry, 31:37853788 .

Wu, C. Y. and Li, H. W. (1978). Labiatae. Fl. Reipubl. Popularis Sin., 65:1649, 66:1-647.

Yoshida, T.; Otaka, T.; Uchiyama, M. and Ogawa, S. (1971). Effect of ecdysterone on hyperglycemia in experimental animals. Biochem. Pharmacol., 20:3263-3268.

Yousaf, T.; Rafique, S.; Wahid, F.; Rehman, S.; Nazir, A.; Rafique, J.; Aslam, K.; Shabir, G. and Shah, S.M. (2018). Phytochemical profiling and antiviral activity of Ajuga bracteosa, Ajuga parviflora, Berberis lycium and Citrus lemon against Hepatitis C virus. Microb. Pathog., 118: $154-158$.

Yun, Y.J.; Do, J.C.; Jung, K.Y.; Kwon, S.Y. and Son, K.H. (1998). Studies on the constituents of the herbs of Ajuga multiflora (I). Korean J. Pharmacogn., 29:75-78.

Zafar H. Israili and Badiâa Lyoussi* (2009). Ethnopharmacology of the plants of genus Ajuga. Pak. J. Pharm. Sci., 22:425-462.

Zeng, X.N.; Coll, J.; Camps, F. and Palacin, M.J. (2003). Analysis of phytoecdysteroids in cultured plants of Ajuga nipponensis makino. J. Asian Nat. Prod. Res., 2:263-269.

Zhang, Y.H.; Cheng, J.K. and Yang, L. (2002). Triterpenoids from Rhaponticum uniflorum. Journal of the Chinese Chemical Society, 49:117-124.

Ziyyat, A.; Legssyer, A.; Mekhfi, H.; Dassouli, A.; Serhrouchni, M. and Benjelloun, W. (1977). Phytotherapy of hypertension and diabetes in Oriental Morocco. J. Ethnopharmacol., 58:45-54.

Citation: Bakhodir Mamarasulov, Kakhramon Davranov and Dilfuza Jabborova (2020). Phytochemical, pharmacological and biological properties of Ajuga turkestanica (Rgl.) Brig (Lamiaceae). Ann. Phytomed., 9(1):44-57. http://dx.doi.org/ 10.21276/ap.2020.9.1.6 